\title{
Bilişim Etiği Değerlerine Yönelik Tutum Ölçeğinin Geliştirilmesi*
}

\author{
Berkay Çelik ${ }^{1}$ ve Kerim Gündoğdu ${ }^{* * 2}$
}

$\ddot{O} z$

Anahtar Sözcükler

Son yıllarda bilişim alanında ortaya çıkan gelişmeler neredeyse her alanda insan yaşamını kolaylaştıran yenilikler sunmaktadır. Teknolojinin yaşamımıza yerleşmesinin olumlu yanları olduğu kadar olumsuz yanları da mevcuttur. Günümüzde teknolojinin sağladığı internet ve sosyal medya olarak adlandırılan sanal ortamlarda bireyler birçok problemle karşılaşmaktadır. Bu bağlamda, bireylerin sanal ortamdaki problemlere yönelik algılarının belirlenmesinin ve bu problemlerin çözümüne yönelik çalışmaların yapılmasının gerekliliği ortaya çıkmaktadır. Bu çalışmada lise düzeyindeki öğrencilerin, bilişim alanında yer alan değerlerle ilgili olarak tutumlarını belirlemeye yönelik bir ölçek geliştirilmesi amaçlanmıştır. Calışmada ilk olarak meslek lisesi bilișim teknolojileri alanında okutulan derslerin öğretim programları, ders kitapları ve literatürde yer alan bilişim ve internet etiği konulu çalışmalar incelenmiştir. Daha sonra bilişism teknolojileri alanında on adet temel değer belirlenmiş ve her bir değeri temsilen toplam 110 taslak madde yazılmıştır. Taslak ölçek maddeleri yedi uzmanın görüşüne sunulmuş ve ölçek 80 maddeye düşürülerek deneme formu hazırlanmıştır. Elde edilen form, meslek liselerinin bilişim teknolojileri alanının 12. sınıfinda okuyan 306 öğrenciye uygulanmıștır. Yapılan faktör analizleri sonucunda sekiz boyut ve 31 maddeden oluşan Bilişim Etiği Değerlerine Yönelik Tutum Ölçeği elde edilmiştir. Ölçeğin tamamı için Cronbach alfa güvenirlik katsayısı 0.798 olarak hesaplanmıştır. Bulgular, ölçeğin güvenilir ve geçerli bir ölçek olarak rahatlıkla kullanılabileceğini göstermektedir.

\author{
Bilișim etiği değerleri \\ İnternet etiğ \\ Değerler eğitimi \\ Bilişim etiğ \\ Makale Hakkında \\ Gönderim Tarihi \\ 11 Temmuz 2019 \\ Kabul Tarihi \\ 06 Aralık 2019 \\ Makale Türï \\ Araștırma Makalesi
}

DOI: $10.12984 /$ egeefd.590560

\section{Developing an Attitude Scale towards Informatics Ethical Values}

\section{Abstract}

In recent years, developments within the field of informatics have offered innovations that facilitate human life. However, the use of technology has both positive and negative effects. Nowadays, many problems are encountered in the internet and social media which people use frequently. Within this understanding, it is necessary to determine the perceptions of individuals about the problems in the virtual environment and to carry out studies to solve these problems. The purpose of this study was to develop an attitude scale determining high school students' attitudes toward different values in informatics. In this study, firstly the vocational high school information technologies courses' curricula, textbooks, studies on informatics, and internet ethics literature were examined. Then, ten basic values were determined in the informatics field and a total of $110 \mathrm{draft}$ items were written to represent each value. The draft scale was reviewed by seven experts, and they were reduced to 80 items in the trial from. 306 students who were in their last year of studies in the informatics branch of vocational high schools filled out the survey. The Informatics Ethical Values attitude scale obtained as a result of factor analysis consists of eight sub-dimensions and 31 items. The reliability (Cronbach alpha) of the scale was found 0.798. According to the results, the scale is a reliable and valid instrument and may be used in future studies.
Keywords

Informatics ethical values

Internet ethics Values education Informatics ethics

Article Info

Received

July 11, 2019

Accepted

December 06, 2019

Article Type

Research Paper

Attf: Çelik, B. ve Gündoğdu, K. (2019). Bilişim etiği değerlerine yönelik tutum ölçeğinin geliştirilmesi. Ege Eğitim Dergisi, 20(2), 335350. doi: $10.12984 /$ egeefd.590560

\footnotetext{
* Bu çalışma, Prof. Dr. Kerim Gündoğdu danışmanlığında yürütülen Animasyon Destekli Değerler Eğitimi Programının Akademik Başarıya Derse Ve Bilişim Değerlerine Yönelik Tutuma ve Kalıcılığa Etkisi başlıklı doktora tezinden üretilmiştir. [This study is produced from the doctoral dissertation titled "The effect of animation based values education curriculum on achievement, attitude toward lesson and informatics related values and retention], supervised by Prof. Dr. Kerim Gündoğdu]

1 (D) İncirliova Ahmet Çallığlu Çok Programlı Anadolu Lisesi, Aydın, Türkiye, berkaycelik09@gmail.com

** Sorumlu Yazar/Corresponding Author

2 (D) Adnan Menderes Üniversitesi, Eğitim Fakültesi, Aydın, Türkiye, kerim.gundogdu@adu.edu.tr
} 


\section{Extended Abstract}

\section{Introduction}

Developments in science and technology make human life easier and offer innovations that improve the quality of life. These developments are of interest to all sectors as well as to the education sector. In this context, the Ministry of National Education constantly updates the curriculum and develops some projects (e.g. FATIH Project) for the wider use of technology in classrooms.

It is a fact that technology poses some problems as well as advantages. People often encounter such problems on the internet and social media. As the internet became widespread in Turkey, as in other countries in the world, the time people spend in social environments started to decrease. In recent years one of the major problems of people is the lack of socialization caused by extensive time spent on internet. In fact, people seem to be less social in everyday life, but they are quite social in the virtual world. Since most people spend a long time on the internet, there are some norms for virtual environments but research shows that people who use the internet excessively do not comply with ethical values. In this context, it is important to determine some values in virtual environments and to teach these values to people. The literature on ethical values within the field of information technology and information technology curriculum is categorized under different values. These values include virtual helpfulness, security, virtual sharing, integrity-honesty, virtual media collaboration, respect for copyright, respect for thought, virtual ethics, virtual bullying etc. This is a scale development study that examines the values of informatics. The study tries to measure the attitudes of people, specifically high school students, towards the values in the field of informatics. In the studies conducted both in Turkey and abroad, various scales have been developed for to measure the values in the field of informatics. However these scales are grouped under the headings of internet ethics and informatics ethics. As a result of an extensive literature review, no scale that measures attitude about values in informatics was found. In addition there is a need for understanding and exploring for the human values and ethics within the field of informatics in this era. Thus, the researchers decided to develop the attitude scale towards Informatics Ethical Values.

\section{Method}

The nature of the study is quantitative. The researchers firstly examined the scales about internet ethics and the curriculum of different lessons within the field of information technologies. Then $110 \mathrm{draft}$ items were decided to be included in the instrument. Then content validity was obtained. The draft instrument of which items were written under different categories (virtual helpfulness, security, virtual share, integrity-honesty, virtual media collaboration, respect for copyright, respect for thought, virtual ethics, virtual bullying) was revised by seven experts. According to experts' feedback, 30 items were eliminated. After the expert feedbacks, the draft form was composed of 80 likert type items and based on four intervals. 311 students answered the research instrument. The mean age for participants was 18. Participants were in their last year of studies in informatics branch of vocational high schools. 306 valid research instruments were obtained at the end of the process.

\section{Findings}

Kaiser Meyer-Olkin (KMO) and Bartlett tests were executed to see the suitability of data for exploratory factor analysis. The KMO test result was significant at 0.84 level. Bartlett sphericity was also (Chi-Square $12544.192 p$ $<0.001)$ significant. These findings showed that exploratory factor analysis can be executed. In the exploratory factor analysis the boundary value for task values in factors where the items take part is regarded as 0.40. Eight factors were emerged. The factors explain the $64.27 \%$ of the total variance. As a result of factor analysis, 49 items were eliminated in line with the factor loads. The 31 items in the attitude scale were loaded between 0.47 and 0.83 for graphics and animation lesson.

In order to verify the dimensions, confirmatory factor analysis was executed. However, in the exploratory factor analysis, it was concluded that not all of the eight dimensions were compatible with each other and should be divided into two groups. Thus, confirmatory factor analysis was performed in two groups. The fit indexes of the scale $($ RMSEA1 $=0.062-$ RMR $1=0.051)$ confirmed the model of related five sub-dimensions and $($ RMSEA $2=$ $0.065-$ RMR2 $=0.058$ ) confirmed the model of related three sub-dimensions. RMSEA and SRMR of the study were appropriate according to the index of conformity. As with Normed Fit Index, Comparative Fit Index and Non-Normed Fit Indexes are well above 0.90 (NFI 0.93, NNFI 0.95, CFI 0.96, IFK 0.96, and RFI 0.92), it may be said that the model stand for a very good fit level. The factors obtained by exploratory factor analysis are also confirmed by confirmatory factor analysis. In order to test the reliability of the scale, Cronbach alpha was obtained. Cronbach alpha coefficients were as follows for the scale and the subscales: 0.798 for the scale, 0.90 
for virtual helpfulness, 0.85 for privacy infringement, 0.76 for respect for copyright, 0.72 for virtual bullying, 0.65 for security, 0.72 virtual media collaboration, 0.74 for virtual ethics, and 0.60 for virtual share subscale.

\section{Discussion and Conclusion}

This is a reliability and validity study of a scale development to determine the attitudes of high school students towards values in the field of informatics. In conclusion, a valid and reliable attitude scale has been developed to measure attitudes towards values in informatics in this study. The scale includes 31 likert type items. The Cronbach's Alpha coefficient of the scale is 0.798 . High scores obtained from the scale indicate that students have high level attitudes towards values in informatics. Probably, the developed scale is the first attitude scale towards values in informatics in Turkish. The Attitude Scale towards Informatics Ethical Values obtained in this study can be used in various research conducted in the fields of education, science, technology, and informatics values. This scale development study is limited to eight IT values determined in the field of informatics. In addition, researchers may be encouraged to carry out new studies that include additional values that may emerge in the field of informatics, supported by qualitative data collection tools. 


\section{Giriş}

Bilim ve teknolojide ortaya çıkan gelişmeler, neredeyse her alanda insan yaşamını kolaylaştıran ve yaşam kalitesini artıran yenilikler sunmaktadır. Ortaya çıkan bu gelişmeler tüm sektörlerde olduğu gibi eğitim sektöründe de yakından izlenmektedir. Eğitimde başarı ancak bireyleri nitelikli, bilişsel olduğu kadar duyuşsal özellikleri de geliştirecek programlar aracılığıyla gerçekleştirilebilir. Öğretim programlarının bulunduğu çağın gereksinimlerini karşılamasının oldukça önemli olduğu (Saracaloğlu, Özyılmaz ve Yeşildere, 2006) ilkesinden yola çıkılarak, eğitim ortamlarının da teknolojiye ayak uydurması ve öğrenme ortamlarının bilimsel gelişmelerden pay alması gerekliliği ortaya çıkmıştır (Güven ve Akar-Vural, 2017; Koç, Şimşek ve Has, 2013). $\mathrm{Bu}$ bağlamda Milli Eğitim Bakanlığı kullanılan öğretim programlarını sürekli olarak güncellemekte ve teknolojinin eğitim-öğretim etkinliklerinde kullanılabilmesi için FATïH (Eğitimde Fursatları Artırma ve Teknolojiyi İyileştirme Hareketi) vb. projelerle öğrenme ortamlarını teknolojik gereçlerle donatmaktadır.

Teknolojinin hayatımızda daha geniş yer bulmasının olumlu tarafları olmasının yanı sıra toplumda bazı sorunları da ortaya çıkardığı bir gerçektir (Yusufoğlu, 2017). Günümüzde teknolojinin sağladığı internet ve sosyal medya olarak adlandırılan sanal ortamlarda bireyler bu sorunlarla sıkça karşılaşmaktadır. Bu bağlamda düşünüldüğünde, eğitim kurumlarından beklenen, bireylere teknolojik alt yapı aracılı̆̆ıla sadece ilgi kazandırmak değil; yaşadıkları topluma uyum sağlayabilmeleri için sosyal, ekonomik ve toplumsal açıdan gelişimlerine yardımcı olmak ve toplumda benimsenen değer yargıların kendilerinden sonra gelecek nesle planlı bir şekilde aktarmaktır (Bozkurt, 2016; Dönmez ve Cömert, 2007). Bu anlamda eğitim kurumlarının görevleri, sadece bilgi ve beceri kazandırmakla sınırlı olmayıp aynı zamanda öğrenen bireylere değerler ve karakter eğitimi anlamında temel bazı toplumsal değerleri benimsetmektir (Ada, Baysal ve Korucu, 2005).

Herhangi bir ortaöğretim kurumunda eğitim almaya başlayana kadar eğitim sürecinin içinde bulunmuş olan bir öğrenci, geçmiş öğrenim hayatı boyunca belirli bir bilgi birikimi elde etmiş sayılır. Lise düzeyindeki bir öğrenci geldiği yaş itibariyle de sürekli olarak çevresiyle etkileşim içerisindedir. İlkokul ve ortaokul döneminde görmüş olduğu derslerde ve almış olduğu eğitimden edindiği kazanımlara göre birey lise çağında kazandığı ve benimsediği değerleri davranış haline getirebilir. Ancak ülkemizde internetin yaygınlaşmaya başladığı 2000'li yılların başından itibaren çocukların, gençlerin ve hatta yetişkinlerin bile günlük yaşamında açık alanlardaki sosyal ortamlarda geçirdikleri süre giderek azalmaya başlamıştır. Özellikle günümüzde insanların en fazla yaşadığı sorunlardan birisi uzun süreli internet kullanımından kaynaklanan asosyalliktir (Akpınar, 2017; Anlı, 2018; Aydın ve Çelik, 2017; Demircioğlu, 2017; Durak ve Seferoğlu, 2016; Erol ve Hassan, 2014; Güleç, 2018; Günel, Turhal ve İmal, 2012; İnce ve Koçak, 2017; Küçükali, 2016; Özsarı ve Battal-Karaduman, 2016; Solmaz, Tekin, Herzem ve Demir, 2013). Aslında birey günlük yaşamda asosyal görünse de sanal ortamda oldukça sosyaldir ve bu ortamda bulunan çevresiyle etkileşim içerisindedir. Bu açıdan bakıldığında gençlerin büyük bir bölümü internet ortamında uzun zaman geçirdiğinden, sanal ortamlara ait birtakım kabul gören normların olması ve bireylerin sanal ortamda iletişim kurarken bu normları ve değerleri benimseme zorunluluğu kaçınılmaz hale gelmektedir. Ancak yapılan araştırmalar, yaşadığımız toplumda sanal ortamı yoğun şekilde kullanan bireylerin uyulması gereken değer yargılarına uymada sıkıntı yaşadığını göstermektedir (Aslanyürek, 2016; Balcı ve Gülnar, 2009; Kır ve Sulak, 2014; Korkmaz ve Mahiroğlu, 2007; Köse, Savran-Gencer ve Gezer, 2007). Bu bağlamda özellikle sanal ortamlarda da standartları bulunan bazı değerlerin belirlenmesi ve bu değerlerin bireylere eğitim yoluyla kazandırılması da akademik açıdan önem arz etmektedir.

Günümüzde teknoloji kullanımı anlamında bilişsel düzeyde oldukça kendini yetiştirmiş bazı bireyler duyuşsal anlamda eksiklik yaşayabilmektedir. Bu durumu ortadan kaldırmanın tek yolu da; bilişim teknolojileri ile ilgili değerlerin bireylere anlatılması, benimsetilmesi ve bireylerin bu değerleri davranış haline dönüsstürmesidir. Bilişim teknolojileri alanında etik değerler ile ilgili alanyazın taramaları ve meslek lisesi bilişim teknolojileri alanında okutulan alan dersleri de göz önünde bulundurulursa öğrencilere benimsetilmesi gereken bilişim değerleri aşağıdaki gibi sıralanabilir:

- Güvenlik

- Sanal Paylaşma

- Doğruluk-Dürüstlük

- Sanal Ortam İşbirliği

- Telif Haklarına Saygı

- Düşünceye Sayg1

- Sanal Yardımseverlik

- Sanal Ortam İşbirliği

- Sanal Ahlak

- Sanal Zorbalık vb.

Bireyler çok uzun bir geçmişe sahip olunmayan, ama yaşantımızın neredeyse vazgeçilmezi haline dönüşen sanal ortamlar ve sosyal medya konusunda bilgi sahibi olmayabilir. Örgün eğitim sürecince verilen derslerde yukarıda 
belirlenen değerlerin öğrencilere kazandırılması ve öğrencilerin bu değerleri içselleştirerek davranış haline getirmesi anahtar öneme sahiptir. Böylece bireylerin hem günlük hayatta hem de sanal ortamlarda uygun etik kararlar vermesi ve etik davranışlar sergilemesine yardımcı olunabilir.

Arslan'a (2009) göre herhangi bir alandaki sorunun giderilebilmesi için öncelikle literatür taraması yapılarak konu ile ilgili çalışmaların incelenmesi ve sorunun temelinin araştırılması gerekmektedir. Bilişim alanındaki değerlere yönelik yapılan alanyazın taramaları sonunda Bilişim Etiği Değerlerine Yönelik Tutum Ölçeği başlı̆̆ altında herhangi bir ölçeğe rastlanmamıştır. Konu ile ilgili olarak yapılan çalışmalara bakıldığında, insanların bilişim teknolojilerinin etik kullanım düzeylerini ve bilişim etiği ile ilgili görüşlerini ortaya çıkarmaya yönelik olarak yapılan araştırmalarda bilişim etiği (Aktay, 2010; Arıkan ve Duymaz, 2014; Arıkan ve Duymaz, 2015; Beyhan ve Tunç, 2012; Duymaz, 2013; Erdem, 2008; Fidan, 2016; Gökçearslan, Günbatar ve Berikan, 2015; Paksoy, 2015), internet ortamındaki etik dışı davranışların, insanların interneti etik kullanma düzeylerinin ve internet etiği algılarının araştırıldığı çalışmalarda internet etiği (Akçin, 2015; Genç, Kazez ve Fidan, 2013; Kayak, 2010; Mısırlı, 2016; Özdemir, 2017; Torun, 2007; Tosun, Geçer ve Kaşıkçı, 2016) ve insanların internet bağımlılığı düzeylerini araştıran çalışmalarda ise internet bağımlılığı (Arıkan, Şimşek ve Kaya, 2012; ÇakırBalta ve Horzum, 2008) başlıkları ön plana çıkmaktadır.

Yurtdışı alanyazın taramasında ise araştırmaların, bilgisayar etiği (Adam ve Ofori-Amanfo, 2000; Cho, Kim ve Kim, 2009; Ghazali, 2003), bilişim ve iletişim etiği (Hur, Kim, Song ve Lee, 2009; Kebbati, 2001), bilişim ve ahlak (Gattiker ve Kelley, 1999), bilişim etiği ve etik karar verme (Dill ve Anderson, 2003; Dorantes, Hewitt ve Goles, 2006; Haines ve Leonard, 2007; Loch ve Conger, 1996; Yoon, 2011) ve internet etiği ve etik kurallara uyma (Friedman, 1997; Lau ve Yuen, 2014; Lou, Shih, Liu, Guo ve Tseng, 2010; Perry, 2010) başlıkları altında birey davranışlarını ölçmeye yönelik çalışmalar olduğu görülmektedir.

Ancak günümüz bilişim çağında özellikle sanal ortamlarda insanların benimsemesi gereken düşünceye sayg1, telif haklarına saygı, sanal yardımseverlik, sanal ortam işbirliği, sanal zorbalık, sanal paylaşma vb. değerlerin de incelendiği ve bireylerin bilişim alanındaki değerlere yönelik tutumunu ölçmeye çalışan bir ölçek geliştirme çalışmasına ihtiyaç duyulmaktadır. Hem ülkemizde hem de yurtdışında yapılan çalışmalarda bilişim alanındaki değerlere yönelik olarak bazı ölçekler geliştirilmiş ancak bu ölçekler daha çok internet etiği ve bilişim etiği başlıkları altında gruplandırılmıştır. Yapılan alanyazın taramasında karşılaşılan araştırmalarda bilişim alanındaki değerleri kapsamlı bir şekilde bir araya getiren bir ölçeğin bulunamaması nedeniyle Bilişim Etiği Değerlerine Yönelik Tutum Ölçeği (BEDTÖ) geliştirme çalışmasının yapılmasına karar verilmiştir. BEDTÖ geliştirme çalışması ile alanyazında tespit edilen eksikliğin giderileceği düşünülmektedir.

\section{Yöntem}

Yapılan bu araştırmada amaç, lise düzeyindeki öğrencilerin bilişim alanındaki değerlere yönelik tutumunu belirlemeye yardımcı olmak amacıyla geçerli ve güvenilir bir ölçme aracı geliştirme çalışması yapmaktır. Bu amaçla nicel araştırma kapsamında bir örneklem seçilmiş ve seçilen örneklem üzerinde ölçeğin deneme uygulaması gerçekleştirilmiştir.

\section{Katılımcilar}

Ölçeğin deneme formu Google formlar yardımıyla internet ortamına aktarılmış ve deneme formunu uygulamak için 2017 - 2018 eğitim yılının güz yarıyılı içerisinde Aydın, Ankara, İstanbul ve İzmir illerindeki çeşitli meslek liselerinin bilişim teknolojileri alanı 12. sınıfında okuyan 311 öğrenci seçkisiz olarak örnekleme dâhil edilmişstir. Çalışmaya katılan öğrencilerin yaş ortalaması 18'dir. Araştırmaya katılan öğrencilerin \% 60'1 kadın ve \% 40'1 erkeklerden oluşmaktadır. Araştırmada bilişim teknolojileri alanındaki değerlere yönelik tutum ölçeği geliştirildiğinden katılımcıların tamamı mesleki eğitim veren okulların bilişim teknolojileri alanında öğrenim gören öğrencilerden seçilmiştir. Deneme uygulaması sonucunda öğrenciler tarafından eksik işaretlenen 5 form çıkarılarak işlemler tam işaretlenmiş 306 form üzerinden yapılmıştır.

\section{Ölçek Geliştirme Süreci}

Bilişim etiği değerlerine yönelik tutum ölçeğini geliştirme sürecinde yapılan işlemler aşağıda detaylı olarak açıklanmıştır.

Literatür Taramasının Yapılması. Bilişim Etiği Değerlerine Yönelik Tutum Ölçeği geliştirmek amacıyla öncelikli olarak bilişim ve internet etiği ile ilgili alanyazın taraması yapılmıştır. Ülkemizde 2000-2018 yılları arasında yapılmış olan ve YÖK tez veri tabanında kayıtlı tezler incelenerek bu çalışmalarda araştırmacılar tarafından bilişim ve internet etiği konulu ölçekler bulunmuş ve ölçek maddeleri kontrol edilmiştir.

Yapılan bu araştırmalarda Akçin (2015) çalışmasında Öğrencilerin Internet Etiğine Uyma Ölçeği’ni, Paksoy (2015) çalışmasında Performans Görevleri Uygulamalarında Bilişim Etiği Öğrenci Davranışları Anketi’ni, Arıkan ve Duymaz (2015) çalışmalarında Gerçek Yaşam Durum Senaryolarlyla Bilişim Etiği Ölçeği ve Bilişim 
Etiği Öğretim Programı Öğrenci Görüşleri Anketi’ni, Genç ve diğerleri (2013) çalışmalarında Çevrimiçi Etik Dışı Davranış̧lar Ölçeği'ni, Beyhan ve Tunç (2012) çalışmalarında Etik Olmayan Bilgisayar Kullanım Davranışları Ölçeği'ni ve Torun (2007) ise çalışmasında Internet Etiği Tutum Ölçeği adlı ölçeği kullanmışlardır. Yapılan yurtdışı alanyazın taramasında genel olarak çalışmaların bilgisayar etiği, internet etiği, internet okuryazarlığı, intihal, gizliliğin ihlali, doğruluk ve fikri mülkiyet konuları ile ilgili olarak yapıldığı görülmektedir. Ayrıca Cho ve diğerleri (2009), ortaokul öğrencilerine yönelik olarak Bilgisayar Etiği Ölçeği adlı ölçeği geliştirmiş ve kullanmışlardır.

$\mathrm{Bu}$ aşamadan sonra meslek liselerinde bulunan bilişim teknolojileri alanı öğrencilerine okutulan tüm derslerin www.megep.meb.gov.tr adresinde yer alan bireysel öğrenme materyalleri (modül ve ders kitapları) incelenerek bu kaynaklarda yer alan değerler eğitimi ile ilgili başlıklar tespit edilmiştir.

Madde Havuzunun Oluşturulması. Araştırmada bilişim etĭği değerlerine yönelik tutum ölçeği geliştirmek amacıyla Milli Eğitim Bakanlığının Mesleki Eğitimi Geliştirme Projesi (MEGEP) kapsamında www.megep.gov.tr adresinde yayımlanan Bilişim Teknolojileri alanına ait derslerin çerçeve öğretim programları, bilgi formları ve yeterlilik tabloları, alan ders modüllerinin içerikleri ve alanyazın taramasında karşılaşılan Öğrencilerin İnternet Etiğine Uyma Ölçeği (Akçin, 2015), İnternet Etiği Tutum Ölçeği (Torun, 2007), Etik Olmayan Bilgisayar Kullanım Davranışları Ölçeği (Beyhan ve Tunç, 2012), Performans Görevleri Uygulamalarında Bilişim Etiği Öğrenci Davranışları Anketi (Paksoy, 2015), Çevrimiçi Etik Dışı Davranışlar Ölçeği (Genç ve diğ., 2013), Gerçek Yaşam Durum Senaryolarıyla Bilişim Etiği Ölçeği (Arıkan ve Duymaz, 2014) ve Bilgisayar Etiği Ölçeği (Cho ve diğ., 2009) maddeleri incelenmiştir.

Bu bağlamda BEDTÖ'de kullanılmak üzere taslak maddeler yazılmaya başlanmıştır. Ölçekte bilişim değerleriyle ilgili olarak on adet değer belirlenerek her bir değerin altına o değerle ilgili aday ölçek maddeleri yazılmıştır. Hazırlanan taslak ölçek toplam 110 maddeden oluşturulmuştur. Oluşturulan maddelerin 11'i gizliliğin ihlali (mahremiyet), 10'u sanal paylaşma, 12'si doğruluk (dürüstlük), 14'ü güvenlik, 10'u telif haklarına sayg1, 9'u düşünceye saygı, 11'i sanal yardımseverlik, 7'si sanal ortam işbirliği, 12'si sanal ahlak ve 14'ü de sanal zorbalık başlığı altında yazılmış ve maddeler uzman kanısına sunulmuştur.

Uzman Görüşünün Alınması. Bilişim Etiği Değerlerine Yönelik Tutum Ölçeği geliştirme sürecinde, ölçeğin kapsam geçerliğini sağlamak amacıyla, hazırlanan ölçek taslağı iki ölçme ve değerlendirme uzmanına, iki program geliştirme uzmanına, iki bilişim teknolojileri uzmanına ve bir dil uzmanına katkı sağlamaları bakımından takdim edilmiştir. Uzmanlardan elde edilen önerilere göre 110 maddeden 30 'u elenmiş ve ölçek taslağ 80 maddeye düşürülmüş, deneme için hazır hale getirilmiştir.

Uzmanlar, dereceleme biçimi olarak (1)- Kesinlikle katılmıyorum, (2)- Katılmıyorum, (3)- Katıllyorum ve (4)Kesinlikle katıllyorum ifadelerinde birleşmiş̧ir. Ölçeğin dereceleme biçiminin 4'lü likert tipinde olmasına karar verilmiştir çünkü tarafsızlık/kararsızlık seçeneğini araştırmaya katılan bireyler şu durumlarda işaretlemektedirler (Shaw ve Wright, 1967 akt. Turan, Şimşek ve Aslan, 2015):

1.Konuyla ilgili herhangi bir fikirleri ve tutumları olmadığı zamanlarda,

2.Konuyla ilgili düşüncelerini ve tutumlarını tam olarak tanımlayamadıklarında,

3.Konuyla ilgili tutumları dengede olduğunda kararsızlık seçeneğini işaretlemektedirler.

Katılımcılar belirlenen bu durumların dışında konuyla hiç ilgilerinin olmadığında ve konuya kayıtsız kaldıklarında (Nowlis, Kahn ve Dhar, 2002), bireysel sorularda vermek istedikleri gerçek cevapları vermekten çekindiklerinde ve cevaplarını gizlediklerinde (Tourangeau, Smith ve Rasinski, 1997), kendilerine uyan cevabı bulamadıklarında, konuyla ilgili yeteri kadar bilgi sahibi olmadıklarında ya da kesin ve net cevap vermekten kaçındıklarında (Stone, 2004) kararsızlık seçeneğini işaretlemektedirler. Bu nedenlerden dolayı 80 maddeli taslak ölçek 4'lü likert tipinde oluşturulmuştur.

Deneme Uygulamasının Gerçekleştirilmesi. Uzman kanısı sonrasında elde edilen ölçek taslağı gerekli biçimsel düzenlemeler yapılarak ve yönerge yazılarak deneme formu halini almıştır. Deneme formunun uygulaması, meslek lisesi bilişim teknolojileri alanı 12. sınıfında okuyan 306 öğrenci üzerinde yapılmıştır.

\section{Verilerin Analizi}

Bu bölümde ilk olarak örneklemden elde edilen verilerin faktör analizi için uygunluk durumunu ortaya koymak için yapılan Bartlett ve Kaiser-Meyer Olkin (KMO) test sonuçlarına bakılmış ve örneklem yeterliği için KMO katsayıs1 0.841 (Chi-Square $12544.192 p<0.001$ ) elde edilmiş ve sonuç anlamlı bulunmuştur. Elde edilen ölçüm sonucuna göre örneklem yeterliğinin iyi düzeyde olduğu görülmektedir. Bu aşamadan sonra ölçeğin temel bileşenlerinin faktör dağılımını ve ölçek boyutlarını görmek amacıyla açımlayıcı faktör analizi (AFA) uygulanmış ve ortaya çıkarılan sekiz boyutlu modeli test etmek için de doğrulayıcı faktör analizi (DFA) yapılmıştır. Son aşamada ise ölçeğin güvenirliğini belirlemek amacıyla da güvenirlik katsayısı (Cronbach Alfa) değeri hesaplanmıştır. 


\section{Bulgular}

Elde edilen ölçek taslağının deneme uygulaması yapıldıktan sonra ortaya çıkan veriler üzerinden faktör yükü 0.40 'ın üstünde çıkan maddeler seçilerek açımlayıcı faktör analizi yapılmıştır. Faktör grupları tespit edilirken özdeğerler (eigen values) ve scree plot test sonuçları ölçüt olarak belirlenmiştir. Özdeğeri (eigen value) 1.00'in üzerindeki maddeler varimaks döndürme yöntemi ile yapılan AFA sonuçlarına göre tespit edilerek sekiz boyutta toplanmıştır. Bu faktörlerin toplam varyansın \% 64.27'sini açıkladığı görülmektedir.

AFA sonucunda boyutların hiçbirinde faktör yükü çıkmayan veya birden fazla boyutta faktör yükü ortaya çıkan (Büyüköztürk, 2006) 5., 6., 7., 8., 9., 10., 11., 14., 16., 17., 18., 19., 21., 22., 23., 24., 26., 27., 31., 32., 33., 36., 37., 38., 39., 40., 41., 42., 43., 44., 45., 46., 47., 48., 49., 50., 53., 59., 60., 63., 64., 66., 70., 72., 73., 74., 78., 79. ve 80. maddeler taslak formdan çıkarılmıştır. AFA sonrası yapılan eleme işleminden sonra ölçekte yer alan 31 maddenin faktör yükleri 0.478 ile 0.831 arasında değişim göstermektedir. Böylece başlangıçta 110 madde olarak belirlenen taslak form, uzman kanısı ile birlikte 80 maddeye düşürülmüş ve yapılan açımlayıcı faktör analizi ile de 31 madde olarak son halini almıştır. Elde edilen maddelere ve faktör yüklerine ait değerler Tablo 1'de gösterilmiştir.

Tablo 1

Bilişim Etiği Değerlerine Yönelik Tutum Ölçeği Madde Faktör Yükleri

\begin{tabular}{|c|c|c|c|c|c|c|c|c|c|c|}
\hline Boyut & Madde No & Madde İçeriği & $\mathrm{F} 1$ & $\mathrm{~F} 2$ & F3 & F4 & F5 & F6 & F7 & F8 \\
\hline \multirow{6}{*}{ 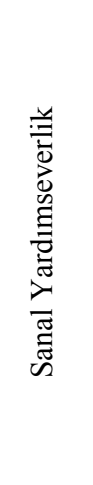 } & S55 & Sanal ortamdaki imza kampanyalarına katılırım. & .831 & & & & & & & \\
\hline & S54 & $\begin{array}{l}\text { Sanal ortamdaki yardım kampanyalarına destek } \\
\text { olmak için kendi profilimde paylaşım yaparım. }\end{array}$ & .820 & & & & & & & \\
\hline & S52 & $\begin{array}{l}\text { Sanal ortamda yardım kampanyası yürüten kişi ya } \\
\text { da kurumlara maddi destek veririm. }\end{array}$ & .802 & & & & & & & \\
\hline & S56 & $\begin{array}{l}\text { Sanal ortamdaki yardım kampanyalarına katılmaları } \\
\text { için arkadaşlarıma haber veririm. }\end{array}$ & .791 & & & & & & & \\
\hline & S51 & Sanal ortamdaki yardım kampanyalarına katılırım. & .789 & & & & & & & \\
\hline & S57 & $\begin{array}{l}\text { İnternet sitelerinde (sosyal medya, forum siteleri } \\
\text { vb.) herhangi bir konuda yardım isteyen kişilerin } \\
\text { sorunlarını çözmek için uğraşırım. }\end{array}$ & .732 & & & & & & & \\
\hline \multirow{5}{*}{ 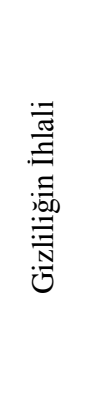 } & S3 & $\begin{array}{l}\text { Başkalarının bilgisayarındaki kişisel dosyaları } \\
\text { habersizce karıştırırım. }\end{array}$ & & .823 & & & & & & \\
\hline & S1 & $\begin{array}{l}\text { Başkalarının sosyal medya hesaplarını gizlice ele } \\
\text { geçirmek için uğraşırım. }\end{array}$ & & .816 & & & & & & \\
\hline & S2 & Başkalarının e-postalarını habersizce okurum. & & .802 & & & & & & \\
\hline & S4 & $\begin{array}{l}\text { Başkalarının bilgisayarlarını trojan vb. programlarla } \\
\text { gizlice ele geçirmek hoşuma gider. }\end{array}$ & & .762 & & & & & & \\
\hline & S20 & $\begin{array}{l}\text { Başkalarını internet ortamında sahte bir hesapla } \\
\text { işletmek hoşuma gider. }\end{array}$ & & .673 & & & & & & \\
\hline \multirow{4}{*}{ 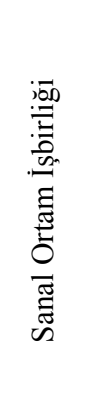 } & S65 & $\begin{array}{l}\text { Sanal ortamlarda tanımadığım kişilerin sorunlarına } \\
\text { çözüm bulmanın ve işbirliğinde bulunmanın vakit } \\
\text { kaybı olduğunu düşünürüm. }\end{array}$ & & & .730 & & & & & \\
\hline & S62 & $\begin{array}{l}\text { Sanal ortamlarda birbirini tanımayan insanların } \\
\text { işbirliğinde bulunarak faydalı bir şey yapacaklarına } \\
\text { inanmam. }\end{array}$ & & & .722 & & & & & \\
\hline & S58 & $\begin{array}{l}\text { Sanal ortamdaki yardım kampanyalarının } \\
\text { doğruluğuna inanmam. }\end{array}$ & & & 676 & & & & & \\
\hline & S61 & $\begin{array}{l}\text { Sanal ortamlarda tanımadığım kişilerle işbirliğinde } \\
\text { bulunmanın sakıncalı olduğunu düşünürüm. }\end{array}$ & & & 645 & & & & & \\
\hline
\end{tabular}


Tablo 1 -devam

\begin{tabular}{|c|c|c|c|c|c|c|c|c|c|c|}
\hline Boyut & Madde No & Madde İçeriği & $\mathrm{F} 1$ & F2 & F3 & F4 & F5 & F6 & F7 & F8 \\
\hline \multirow{4}{*}{ 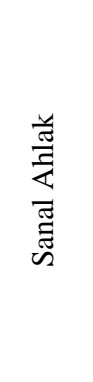 } & S69 & $\begin{array}{l}\text { Karşıma uygunsuz içerikli bir sayfa çıktığında } \\
\text { hemen kapatırım. }\end{array}$ & & & & .802 & & & & \\
\hline & S71 & $\begin{array}{l}\text { Uygunsuz içerikli sitelerden resim veya video } \\
\text { indirmek doğru bir davranış değildir. }\end{array}$ & & & & .732 & & & & \\
\hline & S68 & $\begin{array}{l}\text { Kişilerin internette uygunsuz (başkasını } \\
\text { küçümseyen. cinsel vb.) içerikli sohbet yapmalarını } \\
\text { doğru bulmam. }\end{array}$ & & & & .714 & & & & \\
\hline & S67 & $\begin{array}{l}\text { Sanal sohbet ortamlarında küfürlü yazışmalar } \\
\text { yapmak doğru bir davranış değildir. }\end{array}$ & & & & .691 & & & & \\
\hline \multirow{3}{*}{ : } & $\mathrm{S} 29$ & $\begin{array}{l}\text { Ailemden izin almadan kredi kartını kullanarak } \\
\text { internetten alışveriş yaparım. }\end{array}$ & & & & & .799 & & & \\
\hline & $\mathrm{S} 30$ & $\begin{array}{l}\text { Çeşitli kurumlar adına aradığını söyleyen kişilerle } \\
\text { kişisel bilgilerimi paylaşırım. }\end{array}$ & & & & & .736 & & & \\
\hline & $\mathrm{S} 28$ & $\begin{array}{l}\text { İnternet üzerinden alışveriş vb. işlemlerde kredi kartı } \\
\text { kullanmanın güvenli olduğuna inanırım. }\end{array}$ & & & & & .597 & & & \\
\hline \multirow{3}{*}{ 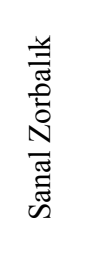 } & S77 & $\begin{array}{l}\text { İnternette tanıştığım kişilere sanal şiddet (tehdit, } \\
\text { şantaj vb.) uygularım. }\end{array}$ & & & & & & .797 & & \\
\hline & S76 & $\begin{array}{l}\text { İnternette tanıştı̆̆ım kişiler tarafından sanal şiddete } \\
\text { (tehdit, şantaj vb.) maruz kalırım. }\end{array}$ & & & & & & .785 & & \\
\hline & S75 & $\begin{array}{l}\text { Kişilere ait uygunsuz içerikli resimlerin internet } \\
\text { ortamında yayımlanmalarında sakınca görmem. }\end{array}$ & & & & & & .635 & & \\
\hline \multirow{3}{*}{ 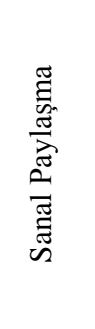 } & $\mathrm{S} 12$ & $\begin{array}{l}\text { İnternette paylaşılan bilgilere anında ulaşmanın } \\
\text { insanları hazıra alıştırdığını düşünürüm. }\end{array}$ & & & & & & & .762 & \\
\hline & S13 & $\begin{array}{l}\text { Başka birinin hazırlayıp internette paylaştı̆̆ bir } \\
\text { ödevi indirip aynen teslim etmenin bana bir fayda } \\
\text { sağlamayacağını düşünürüm. }\end{array}$ & & & & & & & .742 & \\
\hline & S15 & $\begin{array}{l}\text { İnternette ödev. proje vb. paylaşım yapmaya imkân } \\
\text { tanıyan birçok web sitesinin yasaklanması ya da } \\
\text { kapatılması gerektiğini düşünürüm. }\end{array}$ & & & & & & & .478 & \\
\hline \multirow{3}{*}{ 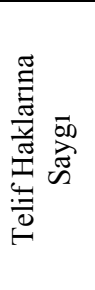 } & S35 & $\begin{array}{l}\text { İnternetten şifre kırılmış (cracklenmiş) programları } \\
\text { indirmekte sakınca görmem. }\end{array}$ & & & & & & & & .804 \\
\hline & S34 & $\begin{array}{l}\text { Lisanslı bir programı üreticisinden onay almadan } \\
\text { şifresi kırılmış (cracklenmiş) olarak internette } \\
\text { dağıtmakta sakınca görmem. }\end{array}$ & & & & & & & & .725 \\
\hline & $\mathrm{S} 25$ & $\begin{array}{l}\text { İnternette üreticinin onayı olmadan çevrimiçi oyun } \\
\text { oynamak beni mutlu eder. }\end{array}$ & & & & & & & & .670 \\
\hline
\end{tabular}

AFA sonrası ortaya çıkan ölçeğin sekiz boyuta sahip olmasına ilişkin olarak modelin testi için doğrulayıcı faktör analizi (DFA) uygulanmıştır. Bu aşamada eldeki veriler LISREL programına aktarılmış ve Path analizi yardımıyla uyum indeksleri hesaplanmıştır. Ancak açımlayıcı faktör analizinde elde edilen sekiz boyutun tamamının kendi içerisinde uyumlu olmadığı ve iki gruba ayrılması gerektiği sonucuna ulaşılmıştır. Bu durumda F1, F2, F5, F6, F8 faktörleri bir grupta F3, F4 ve F7 faktörleri de diğer grupta olmak üzere iki ayr1 grupta doğrulayıc1 faktör analizleri gerçekleştirilmiştir. Şekil 1'de ölçeğin alt boyutlarının birbiriyle ilişkisini gösteren beş faktörlü model verilmiştir. 


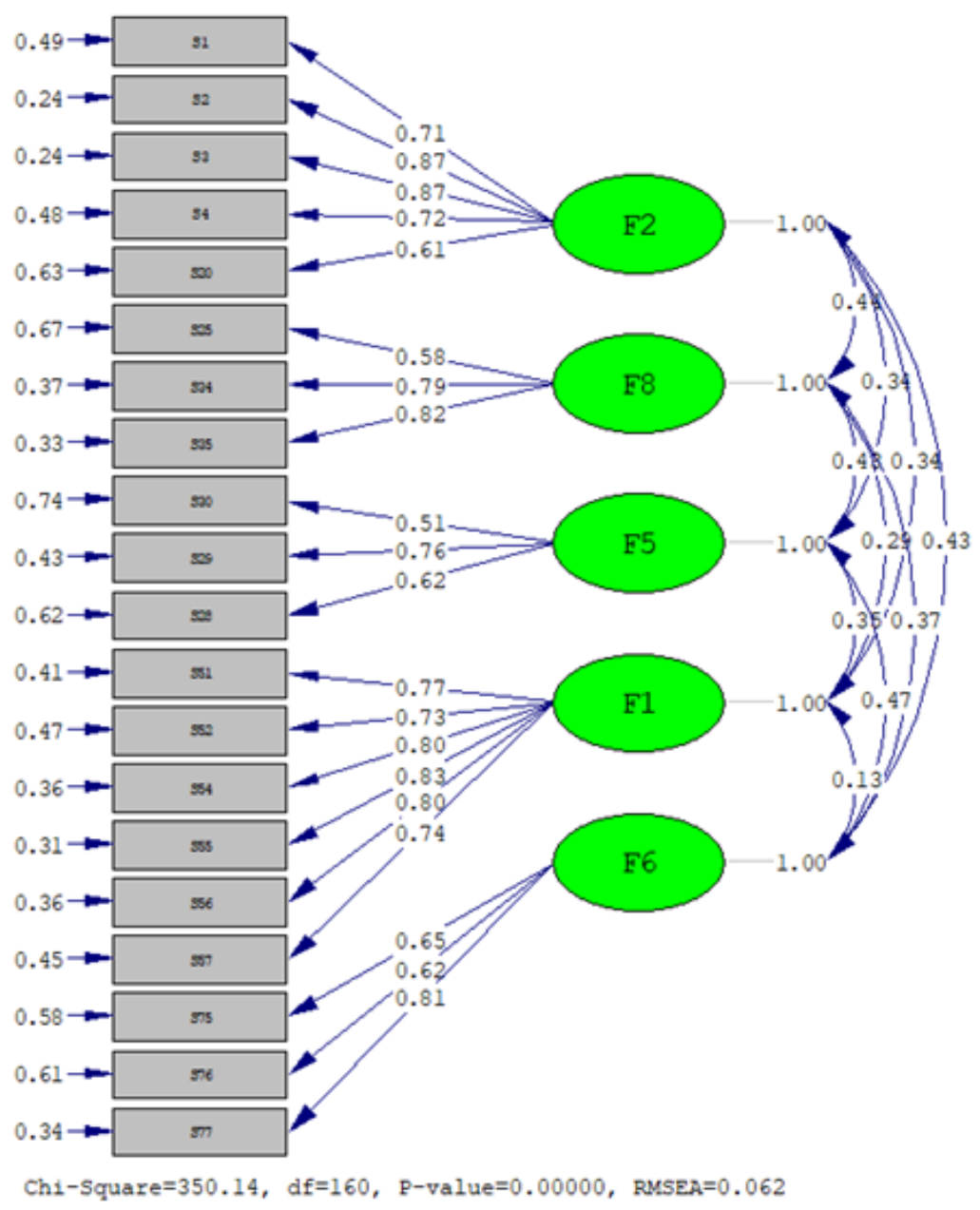

Şekil 1. BEDTÖ’nün Alt Boyutlarının Birbiriyle İlişkisini Gösteren Beş Faktörlü Model

Beş faktörlü modele doğrulayıcı faktör analizi (DFA) uygulanması sonucunda bulunan karşılaştırmalı uyum indeksleri ve olması gereken değer aralıkları Tablo 2'de gösterilmiştir.

Tablo 2

DFA'da Elde Edilen Uyum İyiliği İndeksleri ve Normal Değerler

\begin{tabular}{llllc}
\hline Uyum İndeksleri & DFA Sonucu & Kabul Edilebilir & Normal Değer & Kaynaklar \\
\hline$\chi^{2} /$ sd (Chi-Square/df) & 2.18 & $<5$ & $<2$ & \\
GFI (Goodness of Fit Index) & 0.90 & $>0.90$ & $>0.95$ & \\
IFI (Incremental Fit Index) & 0.96 & $>0.90$ & $>0.95$ & Erkorkmaz ve ark., \\
CFI (Comparative Fit Index) & 0.96 & $>0.90$ & $>0.95$ & $2013 ;$ Byrne, 2010; \\
RFI (Relative Fit Index) & 0.92 & $>0.90$ & $>0.95$ & Hooper, Coughlan ve \\
NFI (Normed Fit Index) & 0.93 & $>0.90$ & $>0.95$ & Mullen, 2008; Hu ve \\
NNFI (Non-Normed Fit Index) & 0.95 & $>0.90$ & $>0.95$ & Bentler, 1995 \\
RMSEA & 0.062 & $<0.08$ & $<0.05$ & $<0.05$ \\
RMR & 0.051 & $<0.08$ & & \\
\hline
\end{tabular}

Hu ve Bentler (1995), RMSEA indeksinin 0.00-0.05 aralığında olmasının çok iyi uyum göstergesi ve 0.05-0.08 uyum aralığının ise kabul edilebilir uyum göstergesi olduğunu belirtmekte ve ayrıca uyum göstergesi olarak (NFI), (NNFI), (CFI) gibi uyum indekslerinin 0.95-0.99 değerleri arasında olmasının çok iyi uyum, 0.90'dan büyük değerde olmasının ise kabul edilebilir uyum olduğunu ifade etmektedir. Şekil 2'de ölçeğin alt boyutları arasındaki ilişkiye işaret eden üç faktöre sahip model yer almaktadır. 


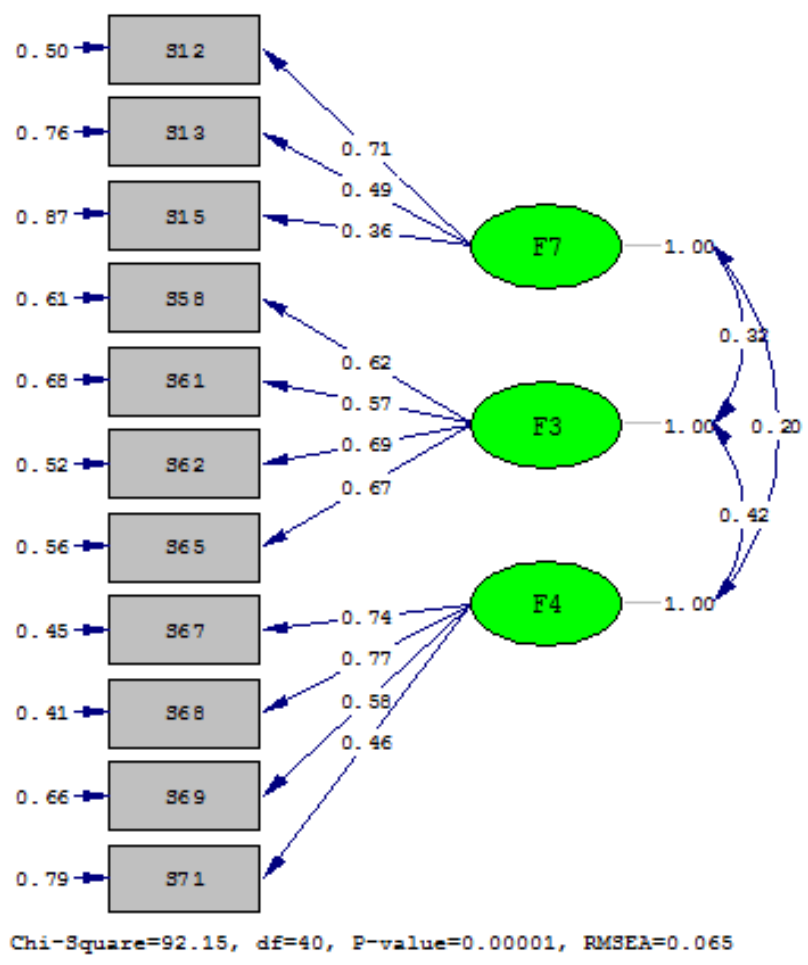

Şekil 2. BEDTÖ’nün Alt Boyutlarının Birbiriyle İlişkisini Gösteren Üç Faktörlü Model

Üç faktörlü modele doğrulayıcı faktör analizi (DFA) uygulanması sonucu elde edilen karşılaştırmalı uyum indeksleri Tablo 3'de verilmiştir.

Tablo 3

DFA'da Elde Edilen Uyum İyiliği İndeksleri ve Normal Değerler

\begin{tabular}{ll}
\hline Uyum İndeksleri & DFA Sonucu \\
\hline$\chi^{2} /$ sd (Chi-Square/df) & 2.30 \\
GFI (Goodness of Fit Index) & 0.95 \\
IFI (Incremental Fit Index) & 0.94 \\
CFI (Comparative Fit Index) & 0.94 \\
RFI (Relative Fit Index) & 0.87 \\
NFI (Normed Fit Index) & 0.90 \\
NNFI (Non-Normed Fit Index) & 0.92 \\
RMSEA & 0.065 \\
RMR & 0.058 \\
\hline
\end{tabular}

Üç faktörlü model için yapılan DFA analizi sonucu incelenmiş ve uyum indekslerinin iyi düzeyde bulunduğu tespit edilmiştir. Böylece ölçeğin yapı geçerliliği de sınanmıştır.

AFA ve DFA sonucu elde edilen ölçütlere göre, Bilişim Etiği Değerlerine Yönelik Tutum Ölçeği'nde yer alan maddelerin elde edilen sekiz alt boyuttaki yapılarla ilgili modellerinin uygun olduğu kararına varılmıştır. Ayrıca ölçeğin güvenirliğinin belirlenmesi amacıyla deneme verileri üzerinde güvenirlik katsayısı (Cronbach Alfa) hesaplaması yapılmıştır. Buna göre ölçeğin tamamı için bulunan güvenirlik katsayısı değeri 0.798'dir. Her boyuta ait güvenirlik değerleri Tablo 4'te görülmektedir. 
Tablo 4

BEDTÖ Alt Boyutlarının Madde Sayıları ve Güvenirliği

\begin{tabular}{lcc}
\hline Boyut & Madde Sayısı & Cronbach Alfa Katsayıs1 \\
\hline Sanal Yardımseverlik & 6 & 0.902 \\
Gizliliğin İhlali & 5 & 0.851 \\
Sanal Ortam İşbirliği & 4 & 0.727 \\
Sanal Ahlak & 4 & 0.748 \\
Güvenlik & 3 & 0.658 \\
Sanal Zorbalık & 3 & 0.720 \\
Sanal Paylaşma & 3 & 0.609 \\
Telif Haklarına Saygı & 3 & 0.763 \\
\hline
\end{tabular}

Sonuç olarak sekiz alt boyuttan oluşan Bilişim Etiği Değerlerine Yönelik Tutum Ölçeği, lise düzeyindeki öğrencilerin bilişim alanındaki değerlere yönelik tutumunu ölçmek amacıyla Türkiye'de geliştirilen ilk ölçektir.

\section{Sonuç ve Tartışma}

Yapılan bu araştırmada, lise seviyesindeki öğrencilerin bilişsim teknolojileri alanındaki değerlerle ilgili tutumunu belirlemek için kullanılması planlanan geçerli ve güvenilir nitelikte bir ölçek geliştirme çalışması yapılmıştır. Geliştirilen ölçek dörtlü likert tipinde cevap verilebilen 31 madde içermektedir (Ek A). Geliştirilen ölçek, sanal yardımseverlik, gizliliğin ihlali, telif haklarına saygı, sanal zorbalık, güvenlik, sanal ortam işbirliği, sanal ahlak ve paylaşma alt boyutları ile ilgili olarak öğrencilerin tutumunu belirlemektedir. Ölçek geliştirme aşamasında yapılan açımlayıcı faktör analizinde varimaks döndürme yöntemi tercih edilmiş ve faktör yükü 0.40 'ın üzerinde olan ve yalnızca tek boyutta faktör yükü veren maddeler ölçeğe alınmıştır. Ölçekte yer alan 31 maddenin 6's1 birinci, 5'i ikinci, 4'ü üçüncü, 4'ü dördüncü, 3'ü beşinci, 3'ü altınc1, 3'ü yedinci ve 3'ü de sekizinci faktörde yer almakta ve bu maddelerin faktör yükleri 0.478 ve 0.831 arasında değişmektedir. Ayrıca ölçekte yer alan faktörler toplam varyansın \% 64.27'sini açıklamaktadır. Ölçek üzerinde gerçekleştirilen doğrulayıcı faktör analizi sonuçlarına göre ölçeğin sekiz boyutunun tamamının birbiriyle uyumlu olmadı̆̆ı, beş faktörün (F1, F2, F5, F6, F8) kendi arasında ve geriye kalan üç faktörün de (F3, F4, F7) kendi arasında uyumlu olduğu sonucuna ulaşılmıştır. Böylece doğrulayıcı faktör analizi iki ayrı grupta gerçekleştirilmiştir. Beş faktörlü $(d f=160$, kikare $=350.14, \mathrm{RMSEA}=0.062, \mathrm{GFI}=0.90, \mathrm{NNFI}=0.95, \mathrm{CFI}=0.96, \mathrm{RMR}=0.051)$ ve üç faktörlü $(d f=40$, kikare $=92.15$, RMSEA $=0.065, \mathrm{GFI}=0.95, \mathrm{NNFI}=0.92, \mathrm{CFI}=0.94, \mathrm{RMR}=0.058$ ) gruplarda ayr1 ayr1 gerçekleştirilen doğrulayıcı faktör analizinde elde edilen sonuçlar beş ve üç faktörlü yapıları doğrulamaktadır. Ölçeğin Cronbach alfa güvenirlik katsayısı tüm boyutlar için $0.798^{\prime}$ dir.

Yapılan alanyazın taramasında bilişim alanındaki değerlerin genellikle bilişim ve internet etiği başlıklı çalışmalar olduğu görülmektedir. Akçin (2015) geliştirmiş olduğu 'Öğrencilerinin İnternet Etiğine Uyma Ölçeği'nde internet etiğini, eğitsel amaçlı internet, genel amaçlı internet ve sosyal amaçlı internet olarak üç alt boyutta toplamıştır. Paksoy (2015) çalışmasında kullandığı Performans Görevleri Uygulamalarında Bilişim Etiği Öğrenci Davranışları Anketinde bilgiye erişim, içerik uygunluğu, kullanıcı gizliliği, fikri mülkiyet, performans görevi alt boyutlarını; Arıkan ve Duymaz (2015) yapmış oldukları Gerçek Yaşam Durum Senaryolarıyla Bilişim Etiği Ölçeğinde gizlilik, müstehcen içerik, ifade özgürlüğü, fikri mülkiyet, yazılım korsanlığı, doğruluk alt boyutlarını; Genç ve diğerleri (2013) geliştirmiş oldukları Çevrimiçi Etik Dışı Davranış Ölçeğinde fikri mülkiyet, doğruluk, gizlilik ve erişim alt boyutlarını; Beyhan ve Tunç (2012) yapmış oldukları ölçek geliştirme çalışmasında Etik Olmayan Bilgisayar Kullanım Davranışları Ölçeğinde toplumsal etki, fikri mülkiyet, ağ doğruluğu, güvenlik ve kalite, etik dışı kullanım ve bilgi doğruluğu alt boyutlarını, Torun (2007) Internet Etiği Tutum Ölçeğinde cinsel içerik, ödev aşırma, bilgisayar korsanlı̆̆ı, internet bağımlılığı, telif hakları, sanal dürüstlük ve şiddet içeren oyunlar alt boyutlarını ve Cho ve diğerleri (2009) ise geliştirmiş oldukları Bilgisayar Etiği Ölçeğinde ölçülü olma, saygılı olma, sorumluluk ve işbirliği alt boyutlarını kullanmışlardır.

Özellikle günümüzde, internet ve sosyal medyanın oldukça yaygın hale gelmesiyle bilimsel araştırmalarda bilişim değerlerinin kapsamlı bir şekilde ele alındığı ölçeklere ihtiyaç duyulması beklenen bir sonuçtur. Çalışma sonucunda elde edilen Bilişim Etiği Değerlerine Yönelik Tutum Ölçeği eğitim, bilim, teknoloji ve bilişim değerleriyle ilgili alanlarda gerçekleştirilecek çeşitli araştırmalarda kullanılabilir. Geliştirilen ölçeğin özellikle teknolojinin öğrenme ve öğretme sürecinde sıkça kullanımında sıklıkla karşılaşabilecek bilişim değerleri ile ilgili duyuşsal özelliklerinin izlenmesine katkı sağlayacağ d düşünülmektedir. Bu araştırmada elde edilen ölçek, bilişim alanında belirlenen sekiz bilişim değeriyle sınılıdır. Bu bağlamda araştırmacılara, bilişim teknolojileri alanında ortaya çıkabilecek yeni değerleri de kapsayan ve nitel veri toplama araçlarıyla desteklenen yeni çalışmalar gerçekleştirmeleri önerilebilir. 


\section{Kaynakça/References}

Ada, S., Baysal, ve N., Korucu, S. (2005). Sınıf öğretmenlerinin sınıf içi olumsuz davranışlara gösterdikleri tepkilerin karakter eğitimi ve 2005 ilköğretim programı açısından değerlendirilmesi. Değerler Eğitimi Dergisi, 3(10), 7-18.

Adam, A. \& Ofori-Amanfo, J. (2000). Does gender matter in computer ethics? Ethics and Information Technology, 2(1), 37-47.

Akçin, R. (2015). Öğretmen algılarına göre ögrrencilerin uygun olmayan internet kullanımları (İstanbul ili örneği. (Yayımlanmamış Yüksek Lisans Tezi). Sakarya Üniversitesi Eğitim Bilimleri Enstitüsü, Sakarya.

Akpınar, E. (2017). AK-TEK sağllkta sosyal medya kullanımı ölçeğinin geliştirilmesi ve aile hekimlerinin sosyal medya kullanımlarının kişisel ve mesleki gelişimlerine etkilerinin değerlendirilmesi. (Uzmanlık Tezi). Çukurova Üniversitesi, Adana.

Aktay, E. (2010). Bilişim etiği ve mobil iletişim için küresel sistem (gsm) sektöründe bir uygulama. (Yayımlanmamış Yüksek Lisans Tezi). Gazi Üniversitesi Sosyal Bilimler Enstitüsü, Ankara.

Anlı, G. (2018). İnternet bağımlılığı: sosyal ve duygusal yalnızlık. Uluslararası Bilimsel Araştırmalar Dergisi. 3(2), 389-397.

Arıkan Y. D., Şimşek Ö. ve Kaya, A. (2012). Öğretmen adaylarının sosyal ăg sitelerini kullanım durumları ve internet bağılmlllı̆̆ düzeyleri. Ankara: Pegem Akademi Yayıncılık.

Arıkan, Y. D. ve Duymaz, S. H. (2014). Gerçek yaşam durum senaryolarıyla bilişim etiği ölçeğini Türkçeye uyarlama çalışması. Ege Ĕ̈itim Dergisi, 15(1), 318-337.

Arıkan, Y. D. ve Duymaz, S. H. (2015). Bilişim etiği öğretimi uygulaması. İlköğretim Online, 14(1), 188-199.

Arslan, M. (2009, Haziran). Türkiye'de yabancı dil edinim sorunu ve yabancı dil olarak Türkçe. First International Symposium Sustainable Development Kongresi'nde sunulan sözel bildiri, Sarajevo-Bosna Hersek.

Aslanyürek, M. (2016). İnternet ve sosyal medya kullanıcılarının internet güvenliği ve çevrimiçi gizlilik ile ilgili kanaatleri ve farkındalıkları. Maltepe Üniversitesi İletişim Fakültesi Dergisi, 3(1), 80-106.

Aydın M. ve Çelik T.(2017). Sosyal bilgiler öğretmen adaylarının sosyal medya kullanım ve doyumlarının incelenmesi. Eğitim Kuram ve Uygulama Araştırmaları Dergisi, 3(2), 82-97.

Balcı, Ş. ve Gülnar, B. (2009). Üniversite öğrencileri arasında internet bağımlılığı ve internet bağımlılarının profili. Selçuk Illetişim Dergisi, 6(1), 5-22.

Beyhan, Ö. ve Tunç, H.S. (2012). Öğretmen adayı öğrencilerin bilişim teknolojilerini etik kullanımlarının incelenmesi. Yükseköğretim Dergisi, 2(2), 85-94.

Bozkurt, S. (2016). Sosyal bilimler liseleri öğrenci velilerinin değer algıları. Eğitim ve Öğretim Araştırmaları Dergisi, 5(4), 126-135

Büyüköztürk, S. (2006). Sosyal bilimler için veri analizi el kitabı. Ankara: Pegem Yayıncılık.

Byrne, B. M. (2010). Multivariate applications series. Structural equation modeling with AMOS: Basic concepts, applications, and programming (2nd Ed.). New York, NY, US: Routledge Taylor \& Francis Group.

Cho, S. H., Kim, K. M., \& Kim, S. S. (2009, Aralı). Computer ethic scale: a study of reliability and validity on the middle school students. Paper presented at the Doctoral Student Consortium Proceedings of the 17th International Conference on Computers in Education. Hong Kong: Asia-Pacific Society for Computers in Education.

Çakır-Balta, Ö.ve Horzum, M.B. (2008). İnternet bağımlılığı testi. Eğitim Bilimleri ve Uygulama Dergisi. 7(13), $87-102$. 
Demircioğlu, Z. (2017). İnternet kullanımının toplumsal ilişkilerin dönüşümü üzerine etkileri. Uluslararası Sosyal Araştırmalar Dergisi. 10(52), 621-627 doi:10.17719/jisr.2017.1922

Dill, B. J., \& Anderson, R. E. (2003). Ethics-related technology policies in schools. Social Science Computer Review, 21(3), 326-339.

Dorantes, C. A., Hewitt, B. \& Goles, T. (2006, January). Ethical decision-making in an IT context: The roles of personal moral philosophies and moral intensity. Proceedings of the 39th Annual Hawaii International Conference on System Sciences (HICSS'06), downloaded at 12.10.2018 from https://ieeexplore.ieee.org/document/1579714

Dönmez, B. ve Cömert, M. (2007). İlköğretim okulu öğretmenlerinin değer sistemleri. Değerler Ĕgitimi Dergisi, 5(14), 29-59.

Durak H. ve Seferoğlu S. S. (2016). Türkiye'de sosyal medya okuryazarlı̆̆ı ve sosyal ağ kullanım örüntülerinin incelenmesi. Uluslararast Sosyal Araştırmalar Dergisi, 9(46), 526-535.

Duymaz, S. H. (2013). Ortaokul öğrencilerine yönelik "biliş̧im etiği öğretim programı" uygulaması. (Yayımlanmamış Yüksek Lisans Tezi). Ege Üniversitesi Fen Bilimleri Enstitüsü, İzmir.

Erdem, Z. (2008). Öğretmen adaylarının biliş̧im teknolojilerini kullanımlarının etik açıdan değerlendirilmesi. (Yayımlanmamış Yüksek Lisans Tezi). Dokuz Eylül Üniversitesi Eğitim Bilimleri Enstitüsü, İzmir.

Erkorkmaz, Ü., Etikan, İ., Demir, O., Özdamar, K. ve Sanisoğlu, S. Y. (2013). Doğrulayıcı faktör analizi ve uyum indeksleri. Türkiye Klinikleri Tip Bilimleri Dergisi, 33(1), 210-223 doi:10.5336/medsci.2011-26747

Erol, G. ve Hassan, A. (2014). Gençlerin sosyal medya kullanımı ve sosyal medya kullanımının tatil tercihlerine etkisi. Uluslararası Sosyal Araştırmalar Dergisi. 7(31), 804-812.

Fidan, M. (2016). Bilişim etiği boyutlarına göre bilişim teknolojileri ve yazılım dersi öğretim programı kazanımlarının incelenmesi. Kastamonu Eğitim Dergisi, 24(4), 1641-1654.

Friedman, B. (1997). Social judgments and technological innovation: adolescents' understanding of property, privacy, and electronic information. Computers in Human Behavior, 13(3), 327-351 doi:10.1016/S07475632(97)00013-7

Gattiker, U. E. \& Kelley, H. (1999). Morality and computer: attitudes and differences in moral judgments. Information Systems Research, 10(3), 233-254.

Genç, Z., Kazez, H. ve Fidan, A. (2013, Ocak). Çevrimiçi etik dışı davranışlarının belirlenmesi için bir ölçek uyarlama çalışması. XV. Akademik Bilişim Konferansında sunulan sözlü bildiri, Akdeniz Üniversitesi, Antalya.

Ghazali, H. (2003). Examining high-school students' views on computer and information ethics. (Yayımlanmamış Doktora Tezi). Kansas State University, Kansas-The USA.

Gökçearslan, Ş. Günbatar, M. S. ve Berikan, B. (2015). Ortaokul öğrencilerinde bilişim etiği: gerçek yaşam durumu senaryolarıyla bir değerlendirme. Ege Eğitim Dergisi, 16(2), 254-273 doi:10.12984/eed.75260

Güleç, V. (2018). Aile ilişkilerinin sosyal medyayla birlikte çöküşü. Yeni Medya Elektronik Dergisi, 2(2), 105120 doi:10.17932/IAU.EJNM.25480200.2018.2/2.105-120

Günel, A., Turhal, Ç. ve İmal, N. (2010, Şubat). İlköğretim öğrencileri arasında internet kullanımının incelenmesine yönelik anket çalı̧̧ması. 3.Ă̆ ve Bilgi Güvenliği Ulusal Sempozyumu Bildirileri, Atılım Üniversitesi, Ankara. http://www.emo.org.tr/ekler/a3ab9ab93998aad_ek.pdf adresinden elde edildi.

Güven, H. \& Akar-Vural, R. (2017). İlkokullarda görev yapan İngilizce öğretmenlerinin akıllı tahta kullanımına ilişkin öz değerlendirmeleri. Adnan Menderes Üniversitesi Sosyal Bilimler Enstitüsü Dergisi, 4(2), 69-86.

Haines, R. \& Leonard, L. N. K. (2007). Individual characteristics and ethical decision-making in an IT context. Industrial Management \& Data Systems, 107(1), 5-20 doi: 10.1108/02635570710719025 
Hooper, D., Coughlan, J. \& Mullen, MR. (2008). Structural equation modelling: guidelines for determining model fit. Electronic Journal of Business Research Methods, 6(1), 53-60 doi:10.21427/D7CF7R

Hu, L. T., \& Bentler, P. M. (1995). Evaluating Model Fit. In R. H. Hoyle (Ed.), Structural Equation Modeling: Concepts, Issues and Applications,76-99. Thousand Oaks, CA: Sage.

Hur, A. J. H., Kim, K.-Y., Song, J.-B., \& Lee, T.-W. (2009). The narrative approach to teach information and communication ethics education in elementary school. Proceedings of the 17th International Conference On Computers in Education, 6, 960-964.

İnce, M. ve Koçak, M. C. (2017). Üniversite öğrencilerinin sosyal medya kullanım alışkanlıkları: Necmettin Erbakan Üniversitesi örneği. Karabük Üniversitesi Sosyal Bilimler Enstitüsü Dergisi, 7(2), 736-749.

Kayak, S. (2010). BÖTE bölümü öğrencilerinin internet etiği algllarının incelenmesi. 10. Uluslararası Ĕgitim Teknolojileri Konferansında (IETC 2010) sunulan sözlü bildiri. Boğaziçi Üniversitesi, İstanbul.

Kebbati, K. (2001). Dealing with ethical issuesi in technology use in a high school classroom. (Unpublished Doctoral Dissertation). Kansas State University, Kansas, USA.

Kır, İ. ve Sulak, Ş. (2014). Eğitim fakültesi öğrencilerinin internet bağımlılık düzeylerinin incelenmesi. Elektronik Sosyal Bilimler Dergisi, 13(51), 50-167. doi:10.17755/esosder.96255

Koç, Y., Şimşek, Ü. \& Has C. (2013). Işık ünitesinin öğretiminde bilgisayar animasyonlarının etkisi. Muş Alparslan Üniversitesi Fen Bilimleri Dergisi. 1(2). 145-156.

Korkmaz, Ö. ve Mahiroğlu A. (2007). İnternet kafelerin kullanım amaçları, yanlış alışkanlıklar ve eğitim düzeyine göre farklılıklar. Ahi Evran Üniversitesi Kırşehir Eğitim Fakültesi Dergisi (KEFAD), 8(2), 99116.

Köse, S., Savran-Gencer, A. ve Gezer, K. (2007). Meslek yüksekokulu öğrencilerinin bilgisayar ve internet kullanımına yönelik tutumları. Pamukkale Üniversitesi Ĕ̈itim Fakültesi Dergisi, 1(21), 44-54.

Küçükali, A. (2016). Üniversite öğrencilerinin sosyal medya kullanımı: Atatürk Üniversitesi örneği. Bartın Üniversitesi İ.I.B.F. Dergisi, 7(13), 531-546.

Lau, W. \& Yuen, A. (2014). Internet ethics of adolescents: understanding demographic differences. Computers \& Education, 72, 378-385.

Loch, K. D., \& Conger, S. (1996). Evaluating ethical decision making and computer use. Communications of the ACM, 39(7), 74-83. doi:10.1145/233977.233999

Lou, S., Shih, R., Liu, H., Guo, Y., \& Tseng, K. (2010). The influences of the sixth graders' parents' internet literacy and parenting style on internet parenting. TOJET: The Turkish Online Journal of Educational Technology, 9(4), 173-184.

Mısırlı Ö. (2016). Öğretmen adaylarının sosyal medyadaki etik davranışlara ilişkin görüşlerinin incelenmesi. (Yayımlanmamış Doktora Tezi). Anadolu Üniversitesi Eğitim Bilimleri Enstitüsü, Eskişehir.

Nowlis, S. M., Kahn, B. E., \& Dhar, R. (2002). Coping with ambivalence: the effect ofremoving a neutral option on consumer attitude and preference judgments. Journal of Consumer Research, 29(3),319-334. doi:10.1086/344431

Özdemir, A. (2017). Yönetim bilişim sistemleri ve bilgisayar ve ögrretim teknolojileri ĕgitimi bölümü ögrencilerinin internet teknolojilerinin etik kullanım düzeylerinin incelenmesi. (Yayımlanmamış Yüksek Lisans Tezi). Aksaray Üniversitesi Sosyal Bilimler Enstitüsü, Aksaray.

Özsarı, İ. ve Batdal-Karaduman, G. (2016). Eğitim fakültesi öğrencilerinin sosyal medya kullanımı ve yalnızlıklarının incelenmesi. Eğitim ve Öğretim Araştırmaları Dergisi, 5(Özel Sayı), 380-389.

Paksoy, M. (2015). Ortaokul öğrencilerinin performans görevlerinde bilişim etik kurallarına uyma durumları. (Yayımlanmamış Yüksek Lisans Tezi). Pamukkale Üniversitesi Eğitim Bilimleri Enstitüsü, Denizli. 
Perry, B. (2010). Exploring academic misconduct: some insights into student behaviour. Active Learning in Higher Education, 11, 97-108.

Saracaloğlu, S., Özyılmaz Akamca, G. ve Yeşildere, S. (2006). İlköğretimde proje tabanlı öğrenmenin yeri. Türk Ĕgitim Bilimleri, 4(3), 241-258.

Solmaz B., Tekin G., Herzem Z. ve Demir M. (2013). İnternet ve sosyal medya kullanımı üzerine bir uygulama (23-32), Selçuk İletişim, 7(4), 23-32.

Stone, M. H. (2004). Substantive scale construction. In E. V. Smith Jr. \& R. M. Smith (Eds.). Introduction to Rasch measurement (pp. 201-225). Maple Grove, MN: JAM Press.

Torun, Ö. (2007). Resmî ortaöğretim kurumlarında öğrenim gören öğrencilerin internet etiğine ilişkin algılarının incelenmesi. (Yayımlanmamış Yüksek Lisans Tezi). Marmara Üniversitesi Eğitim Bilimleri Enstitüsü, İstanbul.

Tosun, N., Geçer, A. ve Kaşıkçı, D. N. (2016). Öğretmen adaylarının internet etiği algıları ve kontrol odağı algıları arasındaki ilişkinin incelenmesi. Açık ögretim Uygulamaları ve Araştırmaları Dergisi, 2(4), 82-103.

Tourangeau, R., Smith, T. W., \& Rasinski, K. A. (1997). Motivation to report sensitive behaviors on surveys: Evidence from a bogus pipeline experiment. Journal of Applied Social Psychology, 27(3), 209-222.

Turan, İ., Şimşek, Ü. ve Aslan, H. (2015). Eğitim araştırmalarında likert ölçeği ve likert-tipi soruların kullanımı ve analizi. Sakarya Üniversitesi Ĕ̆itim Fakültesi Dergisi, 30, 186-203.

Yusufoğlu, Ö. Ş. (2017). Boş zaman faaliyeti olarak akıllı telefonlar ve sosyal yaşam üzerine etkileri: üniversite öğrencileri üzerine bir araştırma. Insan ve Toplum Bilimleri Araştırmaları Dergisi, 6(5), 2414-2434.

Yoon, C. (2011). Ethical decision-making in the internet context: Development and test of an initial model based on moral philosophy. Computers in Human Behavior, 27(6), 2401-2409. doi:10.1016/j.chb.2011.08.007 


\begin{tabular}{|c|c|c|c|c|c|c|}
\hline \multicolumn{7}{|c|}{$\begin{array}{c}\text { Ek A } \\
\text { Bilişim Etiği Değerlerine Yönelik Tutum Ölçeği }\end{array}$} \\
\hline 䨞 & 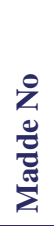 & Madde İçeriği & 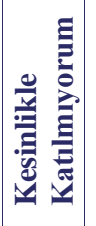 & 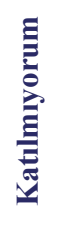 & 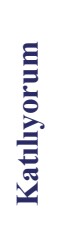 & تِ \\
\hline \multicolumn{7}{|c|}{ Bölüm I } \\
\hline \multirow{6}{*}{ 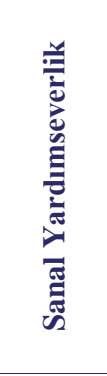 } & 1 & Sanal ortamdaki imza kampanyalarına katılırım. & & & & \\
\hline & 2 & $\begin{array}{l}\text { Sanal ortamdaki yardım kampanyalarına destek olmak için kendi profilimde } \\
\text { paylaşım yaparım. }\end{array}$ & & & & \\
\hline & 3 & $\begin{array}{l}\text { Sanal ortamda yardım kampanyası yürüten kişi ya da kurumlara maddi destek } \\
\text { veririm. }\end{array}$ & & & & \\
\hline & 4 & $\begin{array}{l}\text { Sanal ortamdaki yardım kampanyalarına katılmaları için arkadaşlarıma haber } \\
\text { veririm. }\end{array}$ & & & & \\
\hline & 5 & Sanal ortamdaki yardım kampanyalarına katılırım. & & & & \\
\hline & 6 & $\begin{array}{l}\text { İnternet sitelerinde (sosyal medya, forum siteleri vb.) herhangi bir konuda } \\
\text { yardım isteyen kişilerin sorunlarını çözmek için uğraşırım. }\end{array}$ & & & & \\
\hline \multirow{5}{*}{ 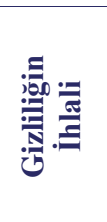 } & 7 & Başkalarının bilgisayarındaki kişisel dosyaları habersizce karıştııırım. & & & & \\
\hline & 8 & Başkalarının sosyal medya hesaplarını gizlice ele geçirmek için uğraşırım. & & & & \\
\hline & 9 & Başkalarının e-postalarını habersizce okurum. & & & & \\
\hline & 10 & $\begin{array}{l}\text { Başkalarının bilgisayarlarını trojan vb. programlarla gizlice ele geçirmek } \\
\text { hoşuma gider. }\end{array}$ & & & & \\
\hline & 11 & Başkalarını internet ortamında sahte bir hesapla işletmek hoşuma gider. & & & & \\
\hline \multirow{3}{*}{ 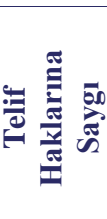 } & 12 & $\begin{array}{l}\text { İnternetten şifre kırılmış (cracklenmiş) programları indirmekte sakınca } \\
\text { görmem. }\end{array}$ & & & & \\
\hline & 13 & $\begin{array}{l}\text { Lisanslı bir programı üreticisinden onay almadan şifresi kırılmış (cracklenmiş) } \\
\text { olarak internette dağıtmakta sakınca görmem. }\end{array}$ & & & & \\
\hline & 14 & İnternette üreticinin onayı olmadan çevrimiçi oyun oynamak beni mutlu eder. & & & & \\
\hline \multirow{3}{*}{ 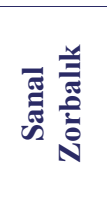 } & 15 & İnternette tanıştığım kişilere sanal şiddet (tehdit, şantaj vb.) uygularım. & & & & \\
\hline & 16 & $\begin{array}{l}\text { İnternette tanıştığım kişiler tarafindan sanal şiddete(tehdit, şantaj vb.) maruz } \\
\text { kalırım. }\end{array}$ & & & & \\
\hline & 17 & $\begin{array}{l}\text { Kişilere ait uygunsuz içerikli resimlerin internet ortamında yayımlanmalarında } \\
\text { sakınca görmem. }\end{array}$ & & & & \\
\hline \multirow{3}{*}{ 泀 } & 18 & Ailemden izin almadan kredi kartını kullanarak internetten alışveriş yaparım. & & & & \\
\hline & 19 & $\begin{array}{l}\text { Çeşitli kurumlar adına aradığını söyleyen kişilerle kişisel bilgilerimi } \\
\text { paylaşırım. }\end{array}$ & & & & \\
\hline & 20 & $\begin{array}{l}\text { İnternet üzerinden alışveriş vb. işlemlerde kredi kartı kullanmanın güvenli } \\
\text { olduğuna inanırım. }\end{array}$ & & & & \\
\hline \multicolumn{7}{|c|}{ Bölüm II } \\
\hline \multirow{4}{*}{ 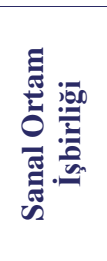 } & 21 & $\begin{array}{l}\text { Sanal ortamlarda tanımadığım kişilerin sorunlarına çözüm bulmanın ve } \\
\text { işbirliğinde bulunmanın vakit kaybı olduğunu düşünürüm. }\end{array}$ & & & & \\
\hline & 22 & $\begin{array}{l}\text { Sanal ortamlarda birbirini tanımayan insanların işbirliğinde bulunarak faydalı } \\
\text { bir şey yapacaklarına inanmam. }\end{array}$ & & & & \\
\hline & 23 & Sanal ortamdaki yardım kampanyalarının doğruluğuna inanmam. & & & & \\
\hline & 24 & $\begin{array}{l}\text { Sanal ortamlarda tanımadığım kişilerle işbirliğinde bulunmanın sakıncalı } \\
\text { olduğunu düşünürüm. }\end{array}$ & & & & \\
\hline \multirow{4}{*}{$\frac{\frac{y}{\mathbb{E}}}{\frac{Z}{E}}$} & 25 & Karşıma uygunsuz içerikli bir sayfa çıktığında hemen kapatırım. & & & & \\
\hline & 26 & $\begin{array}{l}\text { Uygunsuz içerikli sitelerden resim veya video indirmek doğru bir davranış } \\
\text { değildir. }\end{array}$ & & & & \\
\hline & 27 & $\begin{array}{l}\text { Kişilerin internette uygunsuz (başkasını küçümseyen, cinsel vb.) içerikli } \\
\text { sohbet yapmalarını doğru bulmam. }\end{array}$ & & & & \\
\hline & 28 & $\begin{array}{l}\text { Sanal sohbet ortamlarında küfürlü yazışmalar yapmak doğru bir davranış } \\
\text { değildir. }\end{array}$ & & & & \\
\hline \multirow{3}{*}{ 恧 } & 29 & $\begin{array}{l}\text { İnternette paylaşılan bilgilere anında ulaşmanın insanları hazıra alıştırdığını } \\
\text { düşünürüm. }\end{array}$ & & & & \\
\hline & 30 & $\begin{array}{l}\text { Başka birinin hazırlayıp internette paylaştığı bir ödevi indirip aynen teslim } \\
\text { etmenin bana bir fayda sağlamayacağını düşünürüm. }\end{array}$ & & & & \\
\hline & 31 & $\begin{array}{l}\text { İnternette ödev, proje vb. paylaşım yapmaya imkân tanıyan birçok web } \\
\text { sitesinin yasaklanması ya da kapatılması gerektiğini düşünürüm. }\end{array}$ & & & & \\
\hline
\end{tabular}

